\title{
Synthesis and Characterization of New Polyaza Macrocyclic Nickel(II) and Copper(II) Complexes Containing Two Nitrile or Imidate Ester Pendant Arms: Metal-Mediated Hydrolysis and Alcoholysis of the Nitrile Groups
}

\author{
Shin-Geol Kang," Jeonghoon Song, and Jong Hwa Jeong ${ }^{\dagger}$ \\ Department of Chemisty, Daegu University, Kythgsan 712-714, Korea \\ "Department of Chemistry, Kytmgpook National University, Daegu 702-701, Korea \\ Received November 27, 2001
}

\begin{abstract}
New di- $N$-cyanomethylated tetraaza macrocycle 2.13-bis(cyanomethyl)-5.16-dimethyl-2.6.13.17-tetraazatricyclo[ $\left.\left[6.4 .0 .0^{7}\right]^{2}\right]$ docosane $\left(\mathrm{L}^{2}\right)$ has been prepared by the reaction of 3,14-dimethyl-2,6.13,17-tetraazatricyclo $\left[16.4 .0 .0^{7 \cdot 12}\right]$ docosane $\left(\mathrm{L}^{1}\right)$ with bromoacetonitrile. The square-planar complexes $\left[\mathrm{ML}^{2}\right]\left(\mathrm{ClO}_{4}\right)$ : $(\mathrm{M}=$ $\mathrm{Ni}(\mathrm{II})$ or $\mathrm{Cu}(\mathrm{II}))$ can be prepared by the reaction of $\mathrm{L}^{2}$ with the corresponding metal ion in acetonitrile. The cyanomethyl groups of $\left[\mathrm{ML}^{2}\right]\left(\mathrm{ClO}_{4}\right)_{2}$ readily react with water to yield $\left[\mathrm{ML}^{3}\right]\left(\mathrm{ClO}_{4}\right)_{2}$ containing pendant amide groups. The trans-octahedral complexes $\left[\mathrm{ML}^{+}\right]\left(\mathrm{ClO}_{4}\right)_{2}$, in which two imidate ester groups are coordinated to the metal ion, can be also prepared by the reaction of $\left[\mathrm{ML}^{2}\right]\left(\mathrm{ClO}_{4}\right)_{2}$ with methanol under mild conditions. The hydrolysis and alcoholysis reactions of $\left[\mathrm{ML}^{2}\right]\left(\mathrm{ClO}_{4}\right)_{2}$ are promoted by the central metal ion. in spite of the fact that the cyanomethyl group is not involved in intramolecular coordination. The reactions are also promoted by a base such as triethylamine but are retarded by an acid $\left(\mathrm{HClO}_{4}\right)$. Interestingly, the imidate ester groups of $\left[\mathrm{ML}^{4}\right]^{2+}$ are unusually resistant to hydrolysis even in $0.1 \mathrm{M} \mathrm{HClO}_{4}$ or $0.1 \mathrm{M} \mathrm{NaOH}$ aqueous solution. Crystal structure of $\left[\mathrm{NiL}^{+}\right]\left(\mathrm{ClO}_{4}\right)_{2}$ shows that the $\mathrm{Ni}-\mathrm{N}$ (pendant imidate ester group) bond is relatively strong; the $\mathrm{Ni}$ $\mathrm{N}$ bond distance is shorter then the $\mathrm{Ni}-\mathrm{N}$ (tertiary) distance and is similar to the $\mathrm{Ni}-\mathrm{N}$ (secondary) distance.
\end{abstract}

Keywords : Macrocyclic complexes, Functional pendant ams, Hydrolysis, Alcoholysis, X-Ray structure.

\section{Introduction}

There has been considerably interest in the preparation and reactions of polyaza macrocyclic ligands and complexes containing various functional pendant arms. In particular, the interest in such compounds with $-\left(\mathrm{CH}_{2}\right)_{3}-\mathrm{CN}$ pendant arms mainly depends on the fact that the cyanoalkyl groups may be converted to other functional groups. ${ }^{1-8}$ In many transition metal complexes of simple organic nitriles, the metal ion promotes or inhibits certain reactions or allows one to prepare new compounds, which could not be prepared without the involvement of metal ions. ${ }^{9-15}$ It has been also reported that reactions of $N$-cyanoethyl pendant arms in some polyaza macrocyclic complexes are promoted by the central metal ions even if the cyano groups are not involved in coordination. ${ }^{3-6}$ For example, the $14-$ membered tetraaza macrocyclic complex $\left[\mathrm{NiL}^{6}\right]^{2+}$ containing four $N$-cyanoethyl groups is hydrolyzed to $\left[\mathrm{NiL}^{7}\right]^{2-}$ in boiling water. ${ }^{3 .+} \mathrm{How}$ ever, most $N$-cyanoethylated macrocyclic complexes such as $\left[\mathrm{NiL}^{5}\right]^{2-}$ and $\left[\mathrm{NiL}^{6}\right]^{2-}$ undergo metal-promoted decyanoethylation in basic or neutral conditions and, therefore, it is difficult to control the conditions for their selective hydrolysis. ${ }^{3-6}$ On the other hand, the macrocycle $\mathrm{L}^{8}$ containing $N$ cyanomethyl groups is not so easily decyanomethylated even in basic conditions but is selectively hydrolyzed to $L^{9} .78$ Until now, examples of 14-membered tetraaza macrocyclic complexes containing $N$-cyanomethyl pendant arms are rare, and reports on the use of their reactions for the preparation of other functionalized macrocyclic complexes are limited in number. ${ }^{7.8}$
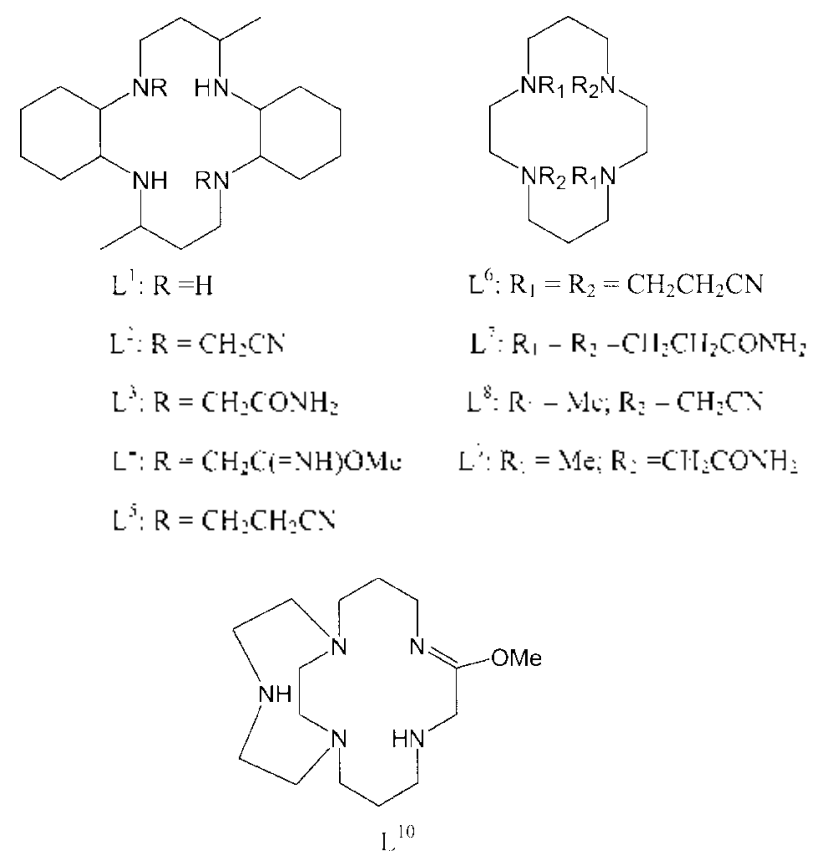

In this work, we prepared the di- $N$-cyanomethylated 14 membered tetraaza macrocyclic complexes $\left[\mathrm{ML}^{2}\right]^{2-}(\mathrm{M}=$ $\mathrm{Ni}(\mathrm{II})$ or $\mathrm{Cu}(\mathrm{II})$ ) and examined their hydrolysis and alcoholysis. It was found that the complexes readily react with water or methanol to yield $\left[\mathrm{ML}^{3}\right]^{2+}$ or $\left[\mathrm{ML}^{+}\right]^{2+}$, in which two amide or imidate ester groups are coordinated to the metal ion. This paper reports the synthesis and properties of new nickel(II) and copper(II) complexes of $\mathrm{L}^{2}$ and $\mathrm{L}^{+}$, together with the crystal structure of $\left[\mathrm{NiL}^{4}\right]\left(\mathrm{ClO}_{4}\right)_{2}$. A number of 
studies have reported on the formation of imidate esters $(\mathrm{RC}(=\mathrm{NH}) \mathrm{OR}$ ) from the metal-promoted reaction of coordinated nitriles $(\mathrm{RCN})$ with alcohols $\left(\mathrm{R}^{\prime} \mathrm{OH}\right) .^{17-1+}$ However, as far as we know, examples of saturated 14-membered tetraaza macrocyclic compounds containing inidate ester pendant arms are not reported to date.

\section{Experimental Section}

Materials and measurements. All chemicals used in syntheses were of reagent grade and were used without further purification. Cattion! Perchlorate salts of metal complexes with organic ligands are often explosive and should be handled with great caution.

Elemental analyses and FAB mass spectra were performed at the Korea Basic Science Institute, Taegu, Korea. Infrared spectra were recorded using a Shimadzu IR-440 spectrophotometer, mass spectra with a Shimadzu GCMSD-QP5050 GC-Mass spectrometer, NMR spectra with a Varian Mecury 300 NMR spectrometer, electronic absorption spectra with a Shimadzu UV-160 spectrophotometer, and conductance measurements with a Metrohm Herisau Conductometer E518. Magnetic moments were calculated from magnetic susceptibility data obtained at $20{ }^{\circ} \mathrm{C}$ using a Johnson Matthey MK-1 magnetic susceptibility balance.

Preparation of $\mathrm{L}^{2}$. The compound $\mathrm{L}^{1}$ was prepared as described before ${ }^{16} \mathrm{~A}$ chloroform solution $(30 \mathrm{~mL})$ of $\mathrm{L}^{1}(2.0$ $\mathrm{g}, 3.7 \mathrm{mmol})$ and bromoacetonitrile $(1.4 \mathrm{~mL}, 18.7 \mathrm{mmol})$ was refluxed for $12 \mathrm{~h}$. After the solvent had been evaporated, methanol $(20 \mathrm{~mL})$ and $0.1 \mathrm{M} \mathrm{NaOH}$ aqueous solution $\left(5 \mathrm{~cm}^{3}\right)$ were added to the residue. The resulting solution was rapidly filtered, and $0.1 \mathrm{M} \mathrm{NaOH}$ solution $\left(20 \mathrm{~mL}^{3}\right)$ was added to the filtrate. The white solid, which had been precipitated, was filtered, washed with methanol-water $(1: 1)$, and dried in air. The compound was recrystallized from methanol-chloroform $(1: 1)$ solution. Yield $-80 \%$. Anal. Found: C, 70.12; $\mathrm{H}, 10.15 ; \mathrm{N}, 20.10$. Calc. for $\mathrm{C}_{24} \mathrm{H}_{42} \mathrm{~N}_{6}$ : C, $69.52 ; \mathrm{H}, 10.21 ; \mathrm{N}, 20.27 \%$. Mass $(\mathrm{m} / \mathrm{z}): 414\left(\mathrm{M}^{-}\right) .{ }^{13} \mathrm{C}$ NMR $\left(\mathrm{CDCl}_{3}\right): \delta 17.4,23.6,24.5,25.7,32.0,32.4,33.2$, $47.1,47.4,54.0,68.1$, and $117.4(\mathrm{C} \equiv \mathrm{N}) . \mathrm{IR}\left(\mathrm{cm}^{-1}\right): 3150$ $[v(\mathrm{~N}-\mathrm{H})]$ and $2240[v(\mathrm{C} \equiv \mathrm{N})]$.

Preparation of $\left[\mathrm{NiL}^{2}\right]\left(\mathrm{ClO}_{4}\right)_{2}$. An acetonitrile suspension $(30 \mathrm{~mL})$ of $\mathrm{L}^{2}(1.0 \mathrm{~g})$ and $\mathrm{Ni}(\mathrm{OAc})_{2} \cdot 4 \mathrm{H}_{2} \mathrm{O}(2.0 \mathrm{~g})$ was refluxed for $30 \mathrm{~min}$ and then cooled to room temperature. The addition of excess $\mathrm{HClO}_{4}$ to the resulting suspension produced an orange-red solid. The solid was collected by filtration and washed with water. The product was recrystallized from a hot DMSO-acetonitrile (2:1) mixture. Yield $-80 \%$. Anal. Found: C, $42.65 ; \mathrm{H}, 6.08 ; \mathrm{N}, 12.24$. Calc. for $\mathrm{C}_{24} \mathrm{H}_{42} \mathrm{~N}_{6} \mathrm{Cl}_{2} \mathrm{NiO}_{8}: \mathrm{C}, 42.88 ; \mathrm{H}, 6.30 ; \mathrm{N}, 12.50 \%$. ${ }^{15} \mathrm{C} \mathrm{NMR}$ (DMSO-d $d_{6}$ ): $\delta 17.9,24.4,24.9,25.9,28.7,31.6,36.5,44.0$, $45.1,52.7,69.7$ and $119.6(\mathrm{CN})$. IR $\left(\mathrm{cm}^{-1}\right): 3140[v(\mathrm{~N}-\mathrm{H})]$ and $2240[v(\mathrm{C} \equiv \mathrm{N})] \cdot \mu_{\mathrm{tff}}=-0.05 \mu_{\mathrm{B}}$. at $20^{\circ} \mathrm{C}$.

Preparation of $\left[\mathrm{NiL}^{3}\right]\left(\mathrm{ClO}_{4}\right)_{2}$. To a hot DMSO-water $(2: 1)$ solution $(30 \mathrm{~mL})$ of $\left[\mathrm{NiL}^{2}\right]\left(\mathrm{ClO}_{4}\right)_{2}(1.0 \mathrm{~g})$ was added triethylamine (3-4 drops). The solution was heated to reflux for $5 \mathrm{~min}$. During this time the orange-red solution turned to pale purple. After filtering the solution, an excess of $\mathrm{NaClO}_{4}$ or $\mathrm{HClO}_{4}$ was added to the filtrate. The purple solid was filtered, washed with water, and dried in air. The product was recrystallized from hot DMSO-water $(2: 1)$ solution. Yield $\sim 90 \%$. Anal. Found: C, 40.41; H, 6.78; N, 12.10. Calc. for $\mathrm{C}_{24} \mathrm{H}_{46} \mathrm{~N}_{6} \mathrm{Cl}_{2} \mathrm{NiO}_{10}: \mathrm{C}, 40.70 ; \mathrm{H}, 6.55 ; \mathrm{N}, 11.87 \%$. FAB Mass $(m / z): 607\left\{\left[\mathrm{M}-\mathrm{ClO}_{4}\right]^{+}\right\}$and $507\left\{\left[\mathrm{M}-\mathrm{H}-2 \mathrm{ClO}_{4}\right]^{-}\right\}$. IR $\left(\mathrm{cm}^{-1}\right): 3330[v(\mathrm{~N}-\mathrm{H})], 3280[v(\mathrm{~N}-\mathrm{H})], 3260[v(\mathrm{~N}-\mathrm{H})]$, $3230[v(\mathrm{~N}-\mathrm{H})], 3180[v(\mathrm{~N}-\mathrm{H})], 1670[v(\mathrm{C}=\mathrm{O})]$, and 1600 $\left[\delta\left(\mathrm{NH}_{2}\right)\right] . \mu_{\mathrm{eff}}=2.92 \mu_{\mathrm{B}}$ at $20^{\circ} \mathrm{C}$.

Preparation of $\left[\mathrm{NiL}^{4}\right]\left(\mathrm{ClO}_{4}\right)_{2}$. To a hot DMSO-methanol $(2: 1)$ solution $(40 \mathrm{~mL})$ of $\left[\mathrm{NiL}^{2}\right]\left(\mathrm{ClO}_{4}\right)_{2}(1.0 \mathrm{~g})$ was added triethylamine (3-4 drops). The solution was refluxed for more then $5 \mathrm{~min}$. After cooling, addition of $\mathrm{HClO}_{4}$ to the solution produced the purple complex. The product was filtered, washed with methanol, and recrystallized from hot DMSO-water $(2: 1)$ solution. Yield $\sim 90 \%$. Anal. Found: $\mathrm{C}$, $42.12 ; \mathrm{H}, 7.03 ; \mathrm{N}, 11.15$. Calc. for $\mathrm{C}_{26} \mathrm{H}_{50} \mathrm{~N}_{6} \mathrm{Cl}_{2} \mathrm{NiO}_{10}: \mathrm{C}$, $42.41 ; \mathrm{H}, 6.84 ; \mathrm{N}, 11.41 \%$. FAB Mass $(m / \mathrm{z}) ; 635$; [M$\left.\mathrm{ClO}_{4}\right]^{-}$and $535\left\{\left[\mathrm{M}-\mathrm{H}-2 \mathrm{ClO}_{4}\right]^{-}\right\}$. IR $\left(\mathrm{cm}^{-1}\right): 3300[v(\mathrm{~N}-$ $\mathrm{H})], 3250[v(\mathrm{~N}-\mathrm{H})]$, and $1660[v(\mathrm{C}=\mathrm{N})] . \mu_{\mathrm{eff}}=2.90 \mu_{\mathrm{B}}$. at $20^{\circ} \mathrm{C}$.

Preparation of $\left[\mathrm{CuL}^{2}\right]\left(\mathrm{ClO}_{4}\right)_{2}$. The red complex was prepared by the method similar to that for $\left[\mathrm{NiL}^{2}\right]\left(\mathrm{ClO}_{4}\right)_{2}$ except that $\mathrm{Cu}(\mathrm{OAc})_{2} \mathrm{H}_{2} \mathrm{O}(2.0 \mathrm{~g})$ was used instead of $\mathrm{Cu}(\mathrm{OAc})_{2} \mathrm{H}_{2} \mathrm{O}(2.0 \mathrm{~g})$. Yield $-80 \%$. Anal. Found: C, 42.22; $\mathrm{H}, 6.31 ; \mathrm{N}, 12.06$. Calc. for $\mathrm{C}_{24} \mathrm{H}_{42} \mathrm{~N}_{6} \mathrm{Cl}_{2} \mathrm{CuO}_{3}: \mathrm{C}, 42.57 ; \mathrm{H}$, $6.20 ; \mathrm{N}, 12.41 \%$. IR $\left(\mathrm{cm}^{-1}\right): 3180[v(\mathrm{~N}-\mathrm{H})]$ and 2250 $[v(\mathrm{C} \equiv \mathrm{N})]$.

Preparation of $\left[\mathrm{CuL}^{3}\right]\left(\mathrm{ClO}_{4}\right)_{2}$. This compound was prepared by the method similar to that for $\left[\mathrm{NiL}^{3}\right]\left(\mathrm{ClO}_{4}\right)_{2}$ except that $\left[\mathrm{CuL}^{2}\right]\left(\mathrm{ClO}_{4}\right)_{2}$ was reacted instead of $\left[\mathrm{NiL}^{2}\right]$ $\left(\mathrm{ClO}_{4}\right)_{2}$. Yield $-90 \%$. Anal. Found: C, 39.95; H, 6.62; N, 11.74. Calc. for $\mathrm{C}_{24} \mathrm{H}_{46} \mathrm{~N}_{6} \mathrm{Cl}_{2} \mathrm{CuO}_{10}: \mathrm{C}, 40.42 ; \mathrm{H}, 6.50 ; \mathrm{N}$, $11.78 \%$. FAB Mass $(m / \mathrm{z}) ; 613\left\{\left[\mathrm{M}-\mathrm{ClO}_{4}\right]^{-}\right\}$and $513\{[\mathrm{M}-\mathrm{H}$ $\left.-2 \mathrm{ClO}_{4}\right]^{-}$, IR $\left(\mathrm{cm}^{-1}\right): 3380[v(\mathrm{~N}-\mathrm{H})], 3290[v(\mathrm{~N}-\mathrm{H})], 3260$ $[v(\mathrm{~N}-\mathrm{H})], 3230[v(\mathrm{~N}-\mathrm{H})], 3175[v(\mathrm{~N}-\mathrm{H})], 1670[v(\mathrm{C}=\mathrm{O})]$, and $1610\left[\delta\left(\mathrm{NH}_{2}\right)\right]$.

Preparation of $\left[\mathrm{CuL}^{4}\right]\left(\mathrm{ClO}_{4}\right)_{2}$. The blue complex was prepared by a procedure similar to that for $\left[\mathrm{NiL}^{4}\right]\left(\mathrm{ClO}_{4}\right)_{2}$ except that $\left[\mathrm{CuL}^{2}\right]\left(\mathrm{ClO}_{4}\right)_{2}$ was reacted instead of $\left[\mathrm{NiL}^{2}\right]$ $\left(\mathrm{ClO}_{4}\right)_{2}$. Yield $-90 \%$. Anal. Found: $\mathrm{C}, 41.95 ; \mathrm{H}, 6.72 ; \mathrm{N}$, 11.18. Calc. for $\mathrm{C}_{26} \mathrm{H}_{50} \mathrm{~N}_{6} \mathrm{Cl}_{2} \mathrm{NiO}_{10}: \mathrm{C}, 42.20 ; \mathrm{H}, 6.82 ; \mathrm{N}$, $11.35 \%$. FAB Mass $(m / z) ; 641\left\{\left[\mathrm{M}-\mathrm{ClO}_{4}\right]^{-}\right\}$and $541\{[\mathrm{M}-\mathrm{H}$ $\left.-2 \mathrm{ClO}_{4}\right]^{-}, \mathrm{IR}\left(\mathrm{cm}^{-1}\right): 3280[v(\mathrm{~N}-\mathrm{H})], 3220[v(\mathrm{~N}-\mathrm{H})]$, and $1670[v(\mathrm{C}=\mathrm{N})]$.

Crystal structure analysis. Crystals of $\left[\mathrm{NiL}^{+}\right]\left(\mathrm{ClO}_{4}\right)_{2}$ suitable for X-ray diffraction study were grown from an acetonitrile-water solution of the complex. Data were collected on an Enraf-Nonius CAD-4 diffractometer in the $\omega-2 \theta$ scan mode. Data reduction was carried out using a Molen program package. ${ }^{17}$ A decay correction based on the intensities of two standard reflections and monitoring every hour was performed; empirical absorption corrections were applied based on $\mathrm{Y}$ scans. The structure in $\mathrm{C} 2 / \mathrm{c}$ for the complex was determined by direct methods and refined by full-matrix least-squares using SHELXS-97 and SHELXL- 
Table 1. Crystal data and structure refinement for $\left[\mathrm{NiL}^{+}\right]\left(\mathrm{ClO}_{4}\right)_{2}$

\begin{tabular}{|c|c|}
\hline Formula & $\mathrm{C}_{26} \mathrm{H}_{50} \mathrm{Cl}_{2} \mathrm{~N}_{6} \mathrm{NiO}_{10}$ \\
\hline M & 736.33 \\
\hline Crystal system (space group) & Monoclinic $(\mathrm{C} 2 / \mathrm{c}(\mathrm{No} .15))$ \\
\hline$a(\AA)$ & $17.321(1)$ \\
\hline$b(\AA)$ & $10.9215(8)$ \\
\hline$c(\AA)$ & $18.185(1)$ \\
\hline$b\left({ }^{\circ}\right)$ & $110.560(6)$ \\
\hline$V\left(\AA^{3}\right)$ & $3220.9(4)$ \\
\hline$Z$ & 4 \\
\hline$D_{\mathrm{c}}\left(\mathrm{gcm}^{-3}\right)$ & 1.518 \\
\hline$m\left(\mathrm{~cm}^{-1}\right)$ & 8.32 \\
\hline$F(000)$ & 1560 \\
\hline$\theta$ range $\left(^{\circ}\right)$ & $2.25-25.46$ \\
\hline Lndex ranges & $0 \leq \mathrm{h} \leq 20,0 \leq \mathrm{k} \leq 13,-2 \mathrm{l} \leq \mathrm{l} \leq 20$ \\
\hline No. of collected / unique & $3180 / 2986\left(R_{\text {tut }}=0.0160\right)$ \\
\hline Data / restraints parameters & $2986 / 0 / 209$ \\
\hline Goodness-of-fit on $F^{2}$ & 1.079 \\
\hline$R$ and $R^{\prime}$ indices $[I>2 \sigma(I)]$ & $0.048,0.132$ \\
\hline$R$ and $R^{*}$ indices (all data) & 0.058 .0 .138 \\
\hline \multicolumn{2}{|c|}{ Largest diff. peak and hole $\left(e \AA^{-3}\right) 0.882$ and -0.615} \\
\hline
\end{tabular}

97 program packages. ${ }^{18}$ Disordered oxygen atoms at $\mathrm{ClO}_{4}$ were refined isotropically at half occupancies and all remaining non-hydrogen atoms were refined anisotropically. Hydrogen atoms at nitrogen atoms were refined, and others were constrained by using riding modes. The geometric parameters are listed in Táble 1.

\section{Results and Discussion}

Synthesis. The reaction of $\mathrm{L}^{1}$ with an excess of cyanomethyl bromide in boiling chloroform produced the $\mathrm{di}-\mathrm{N}$ cyanomethylated macrocycle $\mathrm{L}^{2}$ as the only product. Any other partially or fully $N$-cyanomethylated macrocycle could not be prepared under the present experimental condition. The mass, ${ }^{13} \mathrm{C}-\mathrm{NMR}$, and infrared spectra of the product correspond to $\mathrm{L}^{2}$, in which two cyanomethyl groups are attached to the sterically less hindered nitrogen atoms. The positions of the $N$-substituents was confirmed by the crystal structure of $\left[\mathrm{NiL}^{4}\right]\left(\mathrm{ClO}_{4}\right)_{2}$ (see below). The macrocycle is soluble in chloroform and methanol. The square-planar complexes $\left[\mathrm{NiL}^{2}\right]\left(\mathrm{ClO}_{4}\right)_{2}$ and $\left[\mathrm{CuL}^{2}\right]\left(\mathrm{ClO}_{4}\right)_{2}$ were prepared by the reaction of $\mathrm{L}^{2}$ with the metal ions in acetonitrile.

The complexes $\left[\mathrm{ML}^{2}\right]\left(\mathrm{ClO}_{4}\right)_{2}(\mathrm{M}=\mathrm{Ni}(\mathrm{II})$ or $\mathrm{Cu}(\mathrm{II}))$ are extremely stable in the solid states and in the solutions of DMSO. However, they rapidly react with boiling water to yield $\left[\mathrm{ML}^{3}\right]\left(\mathrm{ClO}_{4}\right)_{2}$ in the presence of a small amount of triethylamine. The octahedral complexes $\left[\mathrm{ML}^{+}\right]\left(\mathrm{ClO}_{4}\right)_{2} \mathrm{con}$ taining two imidate ester groups can be prepared in high yield by the reaction of $\left[\mathrm{ML}^{2}\right]\left(\mathrm{ClO}_{4}\right)_{2}$ with methanol under the similar condition (see Experimental). Although the complexes of $\mathrm{L}^{\xi}$ and $\mathrm{L}^{+}$can be also prepared by refluxing the corresponding solutions of $\left[\mathrm{ML}^{2}\right]\left(\mathrm{ClO}_{+}\right)_{2}$ in the absence of triethylamine, the reaction rate is slower than that in the presence of the base; the hydrolysis and alcoholysis reac- tions of $\left[\mathrm{NiL}^{2}\right]\left(\mathrm{ClO}_{4}\right)_{2}$ require more than 5 min.

We also attempted the hydrolysis and alcoholysis of $\left[\mathrm{NiL}{ }^{5}\right]\left(\mathrm{ClO}_{4}\right)_{2}$ and $\left[\mathrm{CuL}^{5}\right]\left(\mathrm{ClO}_{4}\right)_{2}$ in the presence or absence of trietlylamine. However, the only compound prepared from the attempts was $\left[\mathrm{NiL}^{1}\right]^{2+}$ or $\left[\mathrm{CuL}^{1}\right]^{2-}$, as expected from the reported result that the $N$-cyanoethylated macrocyclic complexes are readily decyanoethylated in boiling water or in basic aqueous solutions. ${ }^{.}$

Crystal structure of $\left[\mathrm{NiL}^{4}\right]\left(\mathrm{ClO}_{4}\right)_{2}$. The crystal structure (Figure 1) of $\left[\mathrm{NiL}^{4}\right]\left(\mathrm{ClO}_{4}\right)_{2}$ shows that the two imidate ester groups are coordinated to the metal ion. The complex has a distorted trans-octahedral coordination geometry, with an inversion center at the metal ion. The six-membered chelate rings and the cyclohexane rings adopt chair conformations. The macrocyclic ligand adopts the trans-III sterochemistry.

Selected bond distances and angles of the complex are listed in Table 2. The $\mathrm{C}(1)-\mathrm{N}(1)$ bond distance $(1.258(5) \AA)$ is much shorter than other $\mathrm{C}-\mathrm{N}$ distances and is corresponding to the $\mathrm{C}=\mathrm{N}$ bond of the imidate ester group. The $\mathrm{C}(1)$ $C(2)[1.493(5) \AA]$ and $C(1)-O(1)[1.328(4) \AA]$ distances are significantly shorter than other $\mathrm{C}-\mathrm{C}$ and $\mathrm{C}(7)-\mathrm{O}(1)$ distances, respectively. The $\mathrm{C}(1)$ atom is located at the trigonal plane of the $\mathrm{N}(1), \mathrm{O}(1)$, and $\mathrm{C}(2)$ atoms. As expected, the $\mathrm{N}(1)$ $\mathrm{C}(1)-\mathrm{O}(1)$ and $\mathrm{N}(1)-\mathrm{C}(1)-\mathrm{C}(2)$ bond angles are much larger

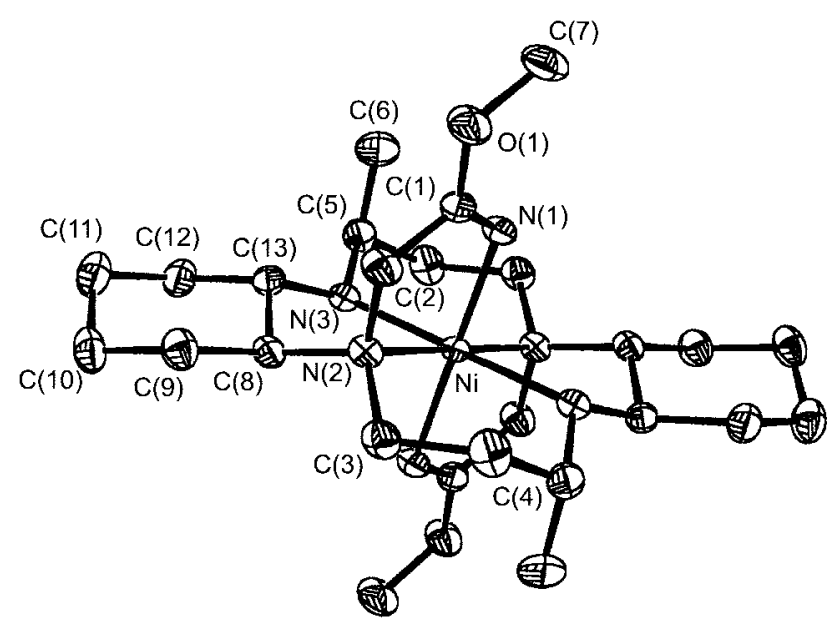

Figure 1. An ORTEX drawing of $\left[\mathrm{NiL}^{\downarrow}\right]^{2+}$.

Table 2. Selected bond distances $(\AA)$ and angles $\left({ }^{\circ}\right)$ of $\left[\mathrm{NiL}^{+}\right]$ $\left(\mathrm{ClO}_{4}\right)_{2}$

\begin{tabular}{lrlr}
\hline $\mathrm{Ni}-\mathrm{N}(1)$ & $2.100(3)$ & $\mathrm{Ni}-\mathrm{N}(2)$ & $2.118(3)$ \\
$\mathrm{Ni}-\mathrm{N}(3)$ & $2.097(3)$ & $\mathrm{C}(1)-\mathrm{N}(1)$ & $1.258(5)$ \\
$\mathrm{C}(2)-\mathrm{N}(2)$ & $1.494(4)$ & $\mathrm{C}(5)-\mathrm{N}(3)$ & $1.495(4)$ \\
$\mathrm{C}(1)-\mathrm{C}(2)$ & $1.493(5)$ & $\mathrm{C}(3)-\mathrm{C}(4)$ & $1.533(5)$ \\
$\mathrm{C}(5)-\mathrm{C}(6)$ & $1.516(6)$ & $\mathrm{C}(10)-\mathrm{C}(11)$ & $1.512(6)$ \\
$\mathrm{C}(1)-\mathrm{O}(1)$ & $1.328(4)$ & $\mathrm{C}(7)-\mathrm{O}(1)$ & $1.439(5)$ \\
$\mathrm{N}(1)-\mathrm{Ni}-\mathrm{N}(1)$ & $180.0(2)$ & $\mathrm{N}(3)-\mathrm{Ni}-\mathrm{N}(3)$ & $180.0(2)$ \\
$\mathrm{N}(1)-\mathrm{Ni}-\mathrm{N}(2)$ & $81.0(2)$ & $\mathrm{N}(1)-\mathrm{Ni}-\mathrm{N}(3)$ & $94.1(2)$ \\
$\mathrm{N}(2)-\mathrm{Ni}-\mathrm{N}(3)$ & $84.1(2)$ & $\mathrm{N}(2)-\mathrm{Ni}-\mathrm{N}(3)$ & $95.9(2)$ \\
$\mathrm{N}(1)-\mathrm{C}(1)-\mathrm{O}(1)$ & $128.2(3)$ & $\mathrm{N}(1)-\mathrm{C}(1)-\mathrm{C}(2)$ & $121.7(3)$ \\
$\mathrm{O}(1)-\mathrm{C}(1)-\mathrm{C}(2)$ & $110.1(3)$ & $\mathrm{C}(1)-\mathrm{O}(1)-\mathrm{C}(7)$ & $117.2(3)$ \\
\hline
\end{tabular}


than the $\mathrm{O}(1)-\mathrm{C}(1)-\mathrm{C}(2)$ angle. The $\mathrm{Ni}-\mathrm{N}$ distances [2.097(3)$2.118(3) \AA]$ are typical for high-spin octahedral nickel(II) complexes with 14-membered tetraaza macrocyclic ligands. The Ni-N(2) (tertiary) distance is longer than the $\mathrm{Ni}-\mathrm{N}(3)$ (secondary) distance, as usual. One of the most remarkable structural features of the complex is that the Ni-N(1) (pendant arm) distance (2.100(3) $\AA$ ) is similar to the $\mathrm{Ni}-\mathrm{N}(3)$ distance and is distinctly shorter than the Ni-N(2) distance. This indicates that the nitrogen atoms of the pendant imidate ester groups are strongly bonded to the metal ion. The Ni$\mathrm{N}$ (1) (pendant arm) distance is also considerably shorter than the axial Ni-O (pendant amido group) distance $(2.302(3) \AA)$ of the trans-octahedral complex $\left[\mathrm{NiL}^{3}\right]\left(\mathrm{ClO}_{4}\right)_{2} .{ }^{19}$ The Ni$\mathrm{N}(1)$ bond is not perpendicular to the in-plane $\mathrm{Ni}-\mathrm{N}$ bonds: the $\mathrm{N}(1)-\mathrm{Ni}-\mathrm{N}(2)$ and $\mathrm{N}(1)-\mathrm{Ni}-\mathrm{N}(3)$ angles are $81.0(2)^{\circ}$ and $94.1(2)^{\circ}$, respectively.

Spectra and properties. The spectral data of $\left[\mathrm{NiL}^{3}\right]$ $\left(\mathrm{ClO}_{4}\right)_{2}$ and $\left[\mathrm{CuL}^{3}\right]\left(\mathrm{ClO}_{4}\right)_{2}$, together with elemental analyzes, are the same as those reported for the corresponding complexes, which have been prepared from the reaction of $\mathrm{L}^{3}$ with $\mathrm{Ni}(\mathrm{II})$ or $\mathrm{Cu}(\mathrm{II})$ ion; the macrocycle $\mathrm{L}^{3}$ was synthesized by the reaction of $\mathrm{L}^{1}$ with 2-chloroacetamide. ${ }^{19}$

The complexes $[\mathrm{ML}]\left(\mathrm{ClO}_{4}\right)_{2}\left(\mathrm{M}=\mathrm{Ni}(\mathrm{II})\right.$ or $\mathrm{Cu}(\mathrm{II}) ; \mathrm{L}=\mathrm{L}^{2}$ or $\left.\mathrm{L}^{+}\right)$are soluble in DMSO but are insoluble in water and methanol at room temperature. In the infrared spectra of $\left[\mathrm{ML}^{4}\right]\left(\mathrm{ClO}_{4}\right)_{2}, v(\mathrm{C}=\mathrm{N})$ of $-\mathrm{C}(=\mathrm{NH})$-OMe groups is observed at $\mathrm{ca} .1660 \mathrm{~cm}^{-1}$. Two bands at $\mathrm{ca} .3300$ and $3250 \mathrm{~cm}^{-1}$ corresponding to $v(\mathrm{~N}-\mathrm{H})$ of the imidate ester groups and the secondary amino groups are also observed. The ${ }^{13} \mathrm{C}$-NMR spectrum of $\left[\mathrm{NiL}^{2}\right]\left(\mathrm{ClO}_{4}\right)_{2}$ is similar to that of $\mathrm{L}^{2}$. The electronic absorption spectral data of the complexes are summarized in Table 3 . The spectrum of $\left[\mathrm{NiL}^{2}\right]\left(\mathrm{ClO}_{4}\right)_{2}$ measured in DMSO shows one $d-d$ transition band at 492 $\mathrm{nm}$ and is comparable with those reported for square-planar nickel(II) complexes of $\mathrm{L}^{5}$ and other related di- $\mathrm{N}$-alkylated 14-membered tetraaza macrocycles. ${ }^{5.20}$ This result as well as the magnetic moment $\left(-0.05 \mu_{\mathrm{B}}\right)$ indicates that the cyanomethyl groups of $\left[\mathrm{NiL}^{-2}\right]\left(\mathrm{ClO}_{4}\right)_{2}$ are not coordinated to the metal ion. The spectra of $\left[\mathrm{NiL}^{+}\right]\left(\mathrm{ClO}_{4}\right)_{2}$ show three bands $(800,513$, and $330 \mathrm{~nm})$ and are comparable with those of $\left[\mathrm{NiL}^{3}\right]\left(\mathrm{ClO}_{4}\right)_{2}$ and other related trans-octahedral nickel(II) complexes. ${ }^{21 \cdot 23}$ The wavelength $(500 \mathrm{~nm})$ for $\left[\mathrm{CuL}^{2}\right]\left(\mathrm{ClO}_{4}\right)_{2}$ measured in Nujol mull is comparable with that for the

Table 3. Electronic absorption spectra of the Nickel(II) complexes ${ }^{a}$

\begin{tabular}{|c|c|c|c|}
\hline Complex & \multicolumn{3}{|c|}{$\lambda_{\max } \operatorname{nm}\left(\varepsilon_{n} \mathrm{M}^{-1} \mathrm{~cm}^{-1}\right)$} \\
\hline$\left[\mathrm{NiL}^{\mathrm{l}}\right]\left(\mathrm{ClO}_{4}\right)_{2}^{{ }^{b}}$ & $468(78)^{i}$ & & \\
\hline$\left[\mathrm{NiL}^{2}\right]\left(\mathrm{ClO}_{4}\right)_{2}$ & $492(77)$ & & \\
\hline$\left[\mathrm{NiL}^{+}\right]\left(\mathrm{ClO}_{4}\right)_{2}$ & $800(5.5)$ & $513(12)$ & $330(\operatorname{sh})$ \\
\hline$\left[\mathrm{NiL}^{5}\right]\left(\mathrm{ClO}_{4}\right)_{2}^{e}$ & $490(115)$ & & \\
\hline$\left[\mathrm{CuL}^{1}\right]\left(\mathrm{ClO}_{4}\right)_{2}^{i}$ & $508(150)^{C}$ & & \\
\hline$\left[\mathrm{CuL}^{2}\right]\left(\mathrm{ClO}_{4}\right)_{2}$ & $540(220)$ & $535(230)$ & $500^{t}$ \\
\hline$\left[\mathrm{CuL}^{4}\right]\left(\mathrm{ClO}_{4}\right)_{2}$ & $570(150)$ & $570(148)^{g}$ & \\
\hline$\left[\mathrm{CuL}^{5}\right]\left(\mathrm{ClO}_{4}\right)_{2}{ }^{e}$ & $490(189)$ & $535(235)$ & \\
\hline
\end{tabular}

In DMSO solution at $20{ }^{\circ} \mathrm{C}$. unless otherwise specified. ${ }^{3}$ Ref. 16. acetonitile. ${ }^{d}{ }_{5 h}=$ shoulder. ${ }^{~}$ Ref. $5 .{ }^{i}$ In Nujol mull. Sn nitromethane. square-planar copper(II) complex $\left[\mathrm{CuL}^{5}\right]\left(\mathrm{ClO}_{4}\right)_{2}$ measured in nitromethane, ${ }^{5}$ indicating that the cyanomethyl groups are not coordinated to the metal ion. In the spectra of the complex measured in DMSO and acetonitrile, the band is observed at ca. $535 \mathrm{~mm}$. The red shift in the solutions may be resulted from the coordination of the solvent molecule. The spectra of $\left[\mathrm{CuL}^{4}\right]\left(\mathrm{ClO}_{4}\right)_{2}$ are also similar to those of $\left[\mathrm{CuL}^{3}\right]\left(\mathrm{ClO}_{4}\right)_{2}$ and other related trans-octahedral copper(II) complexes. ${ }^{19,23}$

Reactivity of the functional pendant arms. As mentioned above, the complexes $\left[\mathrm{ML}^{2}\right]\left(\mathrm{ClO}_{4}\right)_{2}(\mathrm{M}=\mathrm{Ni}(\mathrm{II})$ or $\mathrm{Cu}(\mathrm{II}))$ rapidly react with boiling water or methanol to produce $\left[\mathrm{ML}^{3}\right]\left(\mathrm{ClO}_{4}\right)_{2}$ or $\left[\mathrm{ML}^{4}\right]\left(\mathrm{ClO}_{4}\right)_{2}$, respectively. We examined the reactions under various conditions at $20^{\circ} \mathrm{C}$ to investigate the factors affecting the reactivity of the pendant cyanomethyl groups. It was found that the reaction rate is relatively slow in the absence of any base at $20^{\circ} \mathrm{C}$; the visible absorption spectra of $\left[\mathrm{NiL}^{2}\right]\left(\mathrm{ClO}_{4}\right)_{2}\left(3.0 \times 10^{-3} \mathrm{M}\right)$ measured in water-DMSO $(1: 1)$ or methanol-DMSO $(1: 1)$ solution indicated that $c a .15 \%$ or less than $1 \%$ of the complex was converted to $\left[\mathrm{NiL}^{3}\right]\left(\mathrm{ClO}_{4}\right)_{2}$ or $\left[\mathrm{NiL}^{4}\right]\left(\mathrm{ClO}_{4}\right)_{2}$ in $2 \mathrm{l}$. In the solutions containing 3-4 drops of triethylamine, however, the reactions were completed within $30 \mathrm{~min}$. A similar result was also observed by addition of $\mathrm{NaOH}$ instead of trietlylamine. It is clear that the reactions are accelerated by base, as usual. On the other hand, addition of an acid such as $\mathrm{HClO}_{4}$ to the solutions of $\left[\mathrm{ML}^{2}\right]\left(\mathrm{ClO}_{4}\right)_{2}$ retards the reactions. The spectra of $\left[\mathrm{NiL}^{2}\right]\left(\mathrm{ClO}_{4}\right)_{2}\left(3.0 \times 10^{-3}\right.$ M) measured in $0.1 \mathrm{M} \mathrm{HClO}_{4}$ water-DMSO $(1: 1)$ or methanol-DMSO $(1: 1)$ solution showed that only less than $8 \%$ or $1 \%$ of the complex was converted to $\left[\mathrm{NiL}^{3}\right]\left(\mathrm{ClO}_{4}\right)_{2}$ or $\left[\mathrm{NiL}^{4}\right]\left(\mathrm{ClO}_{4}\right)_{2}$ in $20 \mathrm{~h}$. In the case of the free macrocycle $\mathrm{L}^{2}$, such reactions were not observed during several hours even in boiling aqueous or methanol solutions containing triethylamine (ca. $\left.1.0 \times 10^{-2} \mathrm{M}\right)$.

Above results show that the hydrolysis and alcoholysis of $\left[\mathrm{ML}^{2}\right]\left(\mathrm{ClO}_{4}\right)_{2}$ take place even under the mild conditions and are promoted by the central metal ion even if the cyanomethyl groups are not directly coordinated to the metal ion. It should be mentioned that the pendant arms of the products $\left[\mathrm{ML}^{3}\right]\left(\mathrm{ClO}_{4}\right)_{2}$ and $\left[\mathrm{ML}^{4}\right]\left(\mathrm{ClO}_{4}\right)_{2}$ are coordinated to the metal ion. The fornation of the coordination bonds in the products may be an important factor affecting the reactions, together with the inductive effect of the metal ion in the reactant. ${ }^{3,4,7,8}$

The imidate ester groups of $\left[\mathrm{NiL}^{4}\right]\left(\mathrm{ClO}_{4}\right)_{2}$ and $\left[\mathrm{CuL}^{4}\right]\left(\mathrm{ClO}_{4}\right)_{2}$ are extremely stable in aqueous solutions $(\mathrm{pH}=1-14)$ at room temperature, indicating that they are resistant to hydrolysis. This was also assisted by the fact that the complexes can be recrystallized from hot $\mathrm{HClO}_{4}(0.1 \mathrm{M})$ or $\mathrm{NaOH}(0.1 \mathrm{M})$ solutions without any considerable hydrolysis. Such behavior is in sharp contrast to the generally observed trend that most coordinated or uncoordinated imidate esters readily react with water even at room temperature to give ordinary esters or amides. ${ }^{12-1+}$ For instance, the complex $[\mathrm{NiL}(\mathrm{NH}=$ $\mathrm{C}(\mathrm{OR}) \mathrm{R}) \mathrm{ClO}_{4}(\mathrm{~L}=$ a tridentate anion; $\mathrm{R}=\mathrm{Me}$ or $\mathrm{Et} ; \mathrm{R}=$ $\mathrm{Me}$ or Et), which can be prepared by the alcoholysis of 
$[\mathrm{NiL}(\mathrm{NCR})] \mathrm{ClO}_{4}$, is stable in dry $\mathrm{ROH}$ but is rapidly hydrolyzed to produce the amido complex $\left.\left[\mathrm{NiL} \mathrm{NH}_{2} \mathrm{COR}\right)\right]$ $\mathrm{ClO}_{4}$ if the solvent is wet. ${ }^{1+}$ The copper(II) complex $\left[\mathrm{CuL}^{16}\right]^{2+}$, in which the methoxy group is attached to the imino group of the macrocycle, is also readily hydrolyzed in basic media. ${ }^{2+}$ To our knowledge, $\left[\mathrm{NiL}^{4}\right]\left(\mathrm{ClO}_{4}\right)_{2}$ and $\left[\mathrm{CuL}^{+}\right]\left(\mathrm{ClO}_{4}\right)_{2}$ are rare examples of 14-membered tetraaza macrocylic complexes containing pendant imidate ester groups, which are resistant to acid and base hydrolysis. One of the reasons for the inertness of the complexes may be the strong M-N (imidate ester group) bond.

\section{Conclusions}

New di- $N$-cyanomethylated tetraaza macrocyclic nickel(II) and copper(II) complexes [ML $\left.{ }^{2}\right]^{2+}$ have been prepared. This work shows that the complexes $\left[\mathrm{ML}^{\vdots}\right]^{2-}$ and $\left[\mathrm{ML}^{4}\right]^{2-}$ containing amide or imidate ester groups can be prepared selectively by the metal-promoted hydrolysis or alcoholysis of $\left[\mathrm{ML}^{2}\right]^{2+}$ under mild conditions. The pendant imidate ester groups of $\left[\mathrm{NiL}^{+}\right]^{2+}$ and $\left[\mathrm{CuL}^{4}\right]^{2-}$ are strongly coordinated to the metal ion and are unusually resistant to acid and base hydrolysis.

Acknowledgment. This work was supported by the grant of Daegu University (2001).

\section{References}

1. (a) Aneetha, H.; Lai, Y. H.; Lin. S.-C.; Panneerselvam, K.; Lu, T.H.; Chung. C.-S. J. Chem. Soc., Dalton Trans. 1999, 2885 (b) Wainwright, K. P. J. Chem. Soc., Daton Trans. 1983. 1149. (c) Beer, P. D.; Crowe, D. B.; Ogden, M. I.; Drew, M. G. B.; Main, B. J. Chem. Soc. Dalton Trans. 1993, 2107.

2. Suh. M. P.; Shim, B. Y,; Yoon. T.-S. Ihorg. Chem. 1994, 33, 5509.
3. Wainwright, K. P. J. Chem. Soc., Dalton Trans. 1980, 2117.

4. Freeman. G. M.; Barefield. E. K.; Derveer. D. G. V. Morg. Chen. $1984,23.3092$.

5. Kang, S.-G.: Ryu, K. Bull Korean Chem. Soc. $2000,21,535$.

6. Kang, S.-G.: Ryu, K.; Kim, J. Bull. Korean Chem. Soc. In press

7. Comparone, A.: Kaden, T. A. Helt. Chim Acta 1998, $81,1765$.

8. Kaden, T. A. Chimia 2000, 54,574,

9. Creaser. I. I; Harrowfield. J. M.; Keene. F. R.; Sargeson. A. M. J. An. Chem. Soc. 1981, 103,3559.

10. Sanchez, G.; Serrano, J. L.; de Arellano, M. C. R.: Perez, J.; Lopez, G. Polyhedron 2000, 19, 1395.

11. Segla, P.; Jannicky, M.; Koman, M.: Sima, J.: Glowiak, T. Pollhedron 1998, 17,4525 .

12. Prenzler, P. D.; Hockless. D. C. R.; Heath. G. A. Inorg. Chem. 1997, 36.5845.

13. Michelin, R. A.: Mozzon, M.: Bertani, R. Coord. Chem. Rev: 1996, 147, 299 and references cited therein.

14. Murahashi, S.-1.; Naota, T. Bull. Chem. Soc. Jpn. 1996, 69, 1805 and references cited therein.

15. Paul. P.; Nag. K. Worg. Chem. 1987. 26, 1586.

16. Kang. S.-G.; Kweon, J. K.; Jung. S.-K. Bull. Korean Chem. Soc. $1991,12,483$.

17. Fair, C. K. Molen, An Interactive Intelligent System for Contal Stricture Analysis, Enraf-Nonitis; Deltt: The Netherlands, 1990.

18. (a) Sheldrick, G. M. SHELXS-97, Program for the Solution of Cnstal Strtuctme; University of Göttingen: Göttingen. Germany, 1990. (b) Sheldrick. G. M. SHELXL-97. Program for Crystal Stracture Refinement: Unvversity of Göttingen: Göttingen, Germany, 1997.

19. Choi, K.-Y.; Lee, H.-H.; Park, B.-B.; Kim, J. H.; Kim, J.; Kim, M.-W; Ryu. J.-W.; Suh. M.; Suh, I.-H. Polyhedron 2001. 20, 2002.

20. Kang. S.-G.; Kim. M.-S.; Whang. D.; Kim. K. Inorg. Chim. Acta $1998,279,238$.

21. Pallavicini, P. S.: Perotti, A.; Poggi, A.: Seghi, B.: Fabbrizzi, L. J. 4m. Chem. Soc. 1987, I09, 5139

22. Kang, S.-G.; Kim, M.-S.: Choi, J.-S.; Whang, D.; Kim, K. J. Chent. Soc, Dalton Trans. 1995. 363.

23. Kang. S.-G.; Kim. S.-J.; Jeong. J. H. Polyhedron 1998, 17. 3227.

24. Fortier. D. G.; McAuley, A. J. An. Chen. Soc. 1990. $112,2640$. 